\title{
KEDUDUKAN HARTA WARISAN ANAK DI BAWAH UMUR YANG KEDUA ORANG TUANYA MELANGSUNGKAN PERKAWINAN CAMPUR
}

\author{
Raden Ine Sri Indriani, Prija Djatmika \& Istislam \\ Program Studi Magister Kenotariatan Fakultas Hukum Universitas Brawijaya \\ Jalan Abdul Muis 52-56A, Jakarta, 10160, \\ Email : radeninesriindriani@gmail.com
}

\begin{abstract}
This paper aims to analyze the position of inheritance of minors who have dual citizenship from their parents who make mixed marriages. The method used is normative juridical research, conducted to examine the rules or norms in the law positive. Approach used is the approach of legislation and conceptual approach. The law approach is conducted by reviewing all laws and regulations relating to the legal issues being addressed. The conceptual approach goes from the evolving views and doctrines within law to find ideas that give rise to legal notions, legal concepts, and legal principles relevant to the issues faced. Understanding of these views and doctrines is the foundation for building a legal argument in solving the issues at hand. Minors with dual citizenship may receive inheritance from their mixed marriage parents if: (a) their parent's marriage is valid and recorded; (b) the child is not yet 18 years of age or married; (c) after being even 18 years of age or married, the applicant shall be an Indonesian citizen not later than 3 years.
\end{abstract}

Keywords: Mixed marriage, Minors, Double nationality, Inheritance

\begin{abstract}
Abstrak
Tulisan ini bertujuan untuk menganalisis kedudukan harta warisan anak yang di bawah umur yang memiliki kewarganegaraan ganda dari orang tuanya yang melakukan perkawinan campuran. Metode yang digunakan adalah penelitian yuridis normatif, yang dilakukan untuk mengkaji kaidah-kaidah atau norma-norma dalam hukum positif. Pendekatan yang digunakan adalah pendekatan perundang-undangan dan pendekatan konseptual. Pendekatan undang-undang dilakukan dengan menelaah semua undang-undang dan regulasi yang berkaitan dengan masalah hukum yang sedang ditangani. Pendekatan konseptual beranjak dari pandangan-pandangan dan doktrin-doktrin yang berkembang di dalam ilmu hukum untuk menemukan ide-ide yang melahirkan pengertian-pengertian hukum, konsep-konsep hukum, dan asas-asas hukum relevan dengan isu yang dihadapi. Pemahaman akan pandangan-pandangan dan doktrin-doktrin tersebut merupakan landasan untuk membangun suatu argumentasi hukum dalam memecahkan isu yang dihadapi. Anak di bawah umur yang memiliki kewarganegaraan ganda dapat menerima warisan dari orang tuanya yang melakukan perkawinan campuran, apabila: (a) perkawinan orang tuanya adalah sah dan tercatat; (b) anak belum genap berusia 18 tahun atau menikah; (c) setelah genap 18 tahun atau menikah, yang bersangkutan mengajukan menjadi warga negara Indonesia paling lambat 3 tahun.
\end{abstract}

Kata kunci: Perkawinan campuran, Anak di bawah umur, Kewarganegaraan ganda, Harta warisan 
62 Raden Ine Sri Indriani dkk, Kedudukan Harta Warisan Anak....

\section{Pendahuluan}

Pernikahan merupakan ikatan yang sangat kuat untuk mentaati perintah Allah dan melaksanakannya merupakan ibadah. Oleh karena itu, untuk menjaga kesucian lembaga pernikahan itu, maka pernikahan hanya sah apabila dilakukan menurut hukum agama dan keberadaannya perlu dilindungi oleh hukum negara. Undang-Undang Nomor 1 Tahun 1974 Tentang Perkawinan (untuk selanjutnya disebut "UU Perkawinan"), menyatakan bahwa suatu perkawinan dikatakan sah apabila dilakukan menurut hukum masing-masing agamanya dan kepercayaannya itu. ${ }^{1}$ Selanjutnya di dalam UU Perkawinan menyebutkan juga setiap perkawinan harus dicatatkan menurut peraturan perundangundangan yang berlaku. ${ }^{2}$ Dari ketentuan UU Perkawinan tersebut, maka perkawinan dinyatakan sah apabila: (1) dilakukan menurut hukum agama yang dianutnya, dan (2) perkawinan tersebut dilakukan dan dicatat di hadapan pejabat berwenang yang ditunjuk/berwenang.

Pencatatan perkawinan yang dibuktikan dengan akta otentik berupa akta nikah bertujuan agar terjamin suatu ketertiban dalam suatu perkawinan bagi masyarakat, sehingga setiap perkawinan harus dicatat. Pencatatan perkawinan dilaksanakan oleh Pegawai Pencatat Nikah, sebagaimana diatur dalam Undang-Undang No. 22 Tahun 1946 jo. Undang-Undang No. 32 Tahun 1954 tentang Pencatatan Nikah, Talak dan Rujuk Diseluruh Daerah Luar Jawa dan Madura disebutkan mengenai pengertian pencatatan dimaksud dalam pengertian bahwa setiap perkawinan harus dilangsungkan di hadapan dan di bawah pengawasan Pegawai Pencatat Nikah ${ }^{3}$

Salah satu tujuan perkawinan adalah mendapatkan anak yang dapat meneruskan sejarah hidup. Hal ini dikarenakan anak adalah penerus generasi suatu bangsa, idealnya setiap Anak harus memiliki hak penuh atas pertumbuhan dan perkembangannya secara menyeluruh, baik secara fisik, mental, dan juga sosial. Oleh karenanya, harus diterapkan perlindungan untuk kesejahteraan anak, guna memberikan jaminan terhadap pemenuhan hak-haknya tanpa perlakuan yang diskriminatif dan merugikan anak.

Negara, Pemerintah, Pemerintah Daerah, Masyarakat, Keluarga dan Orang Tua berkewajiban untuk memberikan perlindungan dan menjamin terpenuhinya hak asasi Anak sesuai dengan tugas dan tanggungjawabnya. Pada saat ini perlindungan terhadap Anak belum bisa memberikan jaminan bagi Anak untuk mendapatkan kesempatan dan perlakuan yang sesuai dengan apa yang di butuhkannya dalam aspek bidang kehidupan, maka dalam upaya melaksanakan perlindungan terhadap Hak- hak Anak, oleh Pemerintah harus berdasarkan pada prinsip hak asasi manusia yaitu penghormatan, perlindungan dan pemenuhan atas hak Anak.

Menurut Undang-Undang Republik Indonesia Nomor 35 Tahun 2014 Tentang Perubahan Atas Undang-Undang Nomor 23 Tahun 2002 Tentang Perlindungan Anak, yang dimaksud dengan anak adalah seseorang yang belum -

\footnotetext{
Pasal 2 ayat (1) Undang-Undang Nomor 1 Tahun 1974 Tentang Perkawinan.

Pasal 2 ayat (2) Undang-Undang Nomor 1 Tahun 1974 Tentang Perkawinan.

Undang-Undang No. 32 Tahun 1954 Pasal 6 ayat (1)
} 
berumur 18 (delapan belas) tahun, dan juga anak yang masih di dalam kandungan, ${ }^{4}$ adapun yang dimaksud orang tua adalah ayah dan/atau ibu kandung, atau ayah dan/atau ibu tiri, atau ayah dan/atau ibu angkat. ${ }^{5}$

Salah satu bentuk perlindungan atas hak anak adalah status kewarganegaraan. Hal ini karena warga negara merupakan salah satu unsur hakiki dan unsur pokok suatu negara. Status kewarganegaraan menimbulkan hubungan timbal balik antara warga negara dan negaranya. Setiap warga negara mempunyai hak dan kewajiban terhadap negaranya. Sebaliknya, negara mempunyai kewajiban memberikan perlindungan terhadap, warga negaranya.

Status kewarganegaraan Negara Indonesia diatur pada Undang-Undang Republik Indonesia Nomor 12 Tahun 2006 Tentang Kewarganegaraan Republik Indonesia. Adapun asas-asas yang dianut dalam Undang-Undang ini sebagai berikut:

1. Asas ius sanguinis (law of the blood) adalah asas yang menentukan kewarganegaraan seseorang berdasarkan keturunan, bukan berdasarkan negara. tempat kelahiran.

2. Asas ius soli (law of the soil) secara terbatas adalah asas yang menentukan kewarganegaraan seseorang berdasarkan negara tempat kelahiran, yang diberlakukan terbatas bagi anak-anak sesuai dengan ketentuan yang diatur dalam UndangUndang ini.
3. Asas kewarganegaraan tunggal adalah asas yang menentukan satu kewarganegaraan bagi setiap orang.

4. Asas kewarganegaraan ganda terbatas adalah asas yang menentukan kewarganegaraan ganda bagi anak-anak sesuai dengan ketentuan yang diatur dalam Undang-Undang ini. ${ }^{6}$

Permasalahan kewarganegaraan terhadap anak, seringkali muncul pada perkawinan campuran yang dilakukan oleh orang tuanya. Pada UU 1/1974 pada Pasal 57 dijelaskan bahwa yang dimaksud dengan perkawinan campuran adalah perkawinan dua orang yang ada di Indonesia serta tunduk pada hukum yang berlainan, karena adanya perbedaan kewarganegaraan diantara mereka dan salah satu pihak berkewarganegaraan Indonesia. ${ }^{7}$

Perkawinan campuran sudah merebak ke seluruh pelosok penjuru Tanah Air dan juga kelas masyarakat, dikarnakan oleh adanya globalisasi informasi, ekonomi, pendidikan, dan transportasi dengan mengabaikan pandangan bahwa kawin campur adalah perkawinan antara warga asing yang kaya dan orang Indonesia. ${ }^{8}$ Menurut survei Mixed Couple Club, jalur perkenalan yang membuat pasangan berbeda Negara menikah antara lain adalah perkenalan melalui sosial media, bekas relasi bisnis, teman kerja, bertemu saat berlibur, mantan teman sekolah/kuliah.

Perkawinan campuran juga terjadi pada tenaga kerja Indonesia, dengan tenaga kerja dari -

4 Pasal 1 angka (1) Undang-Undang Republik Indonesia Nomor 35 Tahun 2014 Tentang Perubahan Atas Undang-Undang Nomor 23 Tahun 2002 Tentang Perlindungan Anak

5 Pasal 1 angka (4) Undang-Undang Republik Indonesia Nomor 35 Tahun 2014 Tentang Perubahan Atas Undang-Undang Nomor 23 Tahun 2002 Tentang Perlindungan Anak

6 Penjelasan Undang-Undang Republik Indonesia Nomor 12 Tahun 2006 Tentang Kewarganegaraan Republik Indonesia.

7 Undang Undang Nomor 1 Tahun 1974 Pasal 57.

8 Nuning Hallet, Mencermati Isi Rancangan UU Kewarganegaraan, http://www.mixedcouple.com, diakses 7 Januarii 2018. 


\section{Raden Ine Sri Indriani dkk, Kedudukan Harta Warisan Anak....}

negara lain. ${ }^{9}$ Dengan banyaknya perkawinan campuran di Indonesia, maka sudah seharusnya diperhatikan tentang perlindungan hukum terutama terhadap anak yang dilahirkan dari perkawinan campuran tersebut.

Undang-Undang Nomor 12 Tahun 2006 pada dasarnya tidak mengenal kewarganegaraan ganda (bipatride) ataupun tanpa kewarganegaraan (apatride). Kewarganegaraan ganda yang diberikan kepada anak dalam Undang-Undang ini merupakan suatu pengecualian. ${ }^{10}$

Berdasarkan UU Nomor 12 Tahun 2006, anak yang lahir dari perkawinan seorang wanita WNI dengan pria WNA, maupun anak yang lahir dari perkawinan seorang wanita WNA dengan pria WNI, sama-sama diakui sebagai warga negara Indonesia. ${ }^{11}$ Anak tersebut akan berkewarganegaraan ganda, dan setelah anak berusia 18 tahun atau sudah kawin maka ia harus menentukan pilihannya. ${ }^{12}$ Pernyataan untuk memilih tersebut harus disampaikan paling lambat 3 (tiga) tahun setelah anak berusia 18 tahun atau setelah kawin. ${ }^{13}$

UU 12/2006 tersebut merupakan pengganti Undang Undang No 62 Tahun 1958 tentang Kewarganegaraan. Perubahan ini membawa dampak positif dan negatif bagi setiap Warga Negara Indonesia yang melakukan perkawinan dengan Warga Negara Asing. Perubahan baru ini membuat banyaknya WNI memiliki dwi-kewarganegaraan.

Sebagai contoh kasus yang terdapat pada Putusan Nomor: 141/G/2010/PTUN-Jkt bahwa Swita Motiram sebelumnya tinggal di Indonesia dan memiliki saudara kandung bernama Kamlesh Motiram Kalwani dan Johny Motiram warga Indonesia dan tinggal di Indonesia. Pada suatu ketika Swita Motiram bekerja di luar negeri (Hongkong) dengan tercatat sebagai warga negara India, dan menikah dengan Rattan Ladharam warga negara Hongkong, dan memiliki anak bernama Sunesh Rattan Ladharam. Setelah kembali ke Indonesia dan menjadi warga Indonesia, perkawinan antara Swita Motiram dan Rattan Ladharam tidak didaftarkan di Indonesia. Oleh karena itu, permasalahan yang muncul di kemudian hari adalah Sunesh Rattan Ladharam (anak Swita Motiram dan Rattan Ladharam) sebagai warga asing terkendala untuk mewarisi harta peninggalan orang tuanya. Cuplikan kasus tersebut dapat dilihat di bawah ini.

Bahwa SWITA MOTIRAM dahulu pernah menikah di Luar Negeri (Hongkong) dengan seorang Warga Negara asing bernama RATTAN LADHARAM pada tanggal 10 Desember 1979 sesuai dengan Certificate Of Marriage No. 534375 dan telah bercerai pada tanggal 11 Mei 1990 berdasarkan Putusan Pengadilan Negeri Hongkong Jurisdiksi Perceraian No. 4014 tahun 1988. Bahwa kemudian SWITA MOTIRAM pada tanggal 13 Juni 1997 menjadi Warga Negara Indonesia, berdasarkan Keputusan Presiden Republik Indonesia No. 15/PWI tahun 1997. Bahwa SWITA MOTIRAM setelah menjadi Warga Negara Indonesia tidak pernah mendaftarkan perkawinan dan perceraian yang dilakukan di Hongkong serta anak yang dilahirkan, (SUNESH RATTAN LADHARAM) tersebut pada -

\footnotetext{
Ibid.

10 Penjelasan Undang-Undang Republik Indonesia Nomor 12 Tahun 2006 Tentang Kewarganegaraan Republik Indonesia

11 Pasal 4 huruf c dan d.Undang Undang Nomor 12 Tahun 2006 Trntang Kewarganegaraan Republik Indonesia

12 Pasal 6 ayat (1) Undang Undang Nomor 12 Tahun 2006 Trntang Kewarganegaraan Republik Indonesia

13 Pasal 6 ayat (3) Undang Undang Nomor 12 Tahun 2006 Trntang Kewarganegaraan Republik Indonesia
} 
Kantor Pencatatan Perkawinan di Indones ia, sehingga ia menjadi warga Negara yang berstatus lajang, hal tersebut sebagaimana diatur dalam Pasal 56 ayat 2 Undang- undang No. 1 Tahun 1974 ten tang perkawianan yang berbunyi: "Dalam waktu 1 (satu) tahun setelah suami istri itu kembali di wilayah Indones ia surat bukti perkawinan mereka harus didaftarkan di Kantor Pencatatan Perkawinan tempat tingga I mereka". Bahwa dengan tidak didaftarkannya bukti perkawinan, perceraian yang di lakukan di luar negeri (Hongkong) serta anak yang di lahirkan (SUNESH RATTAN LADHARAM ) pada Kantor Pencatatan Perkawianan di Indones ia maka perkawinan, perceraian dan anak tersebut dianggap tidak ada atau tidak syah. Bahwa dengan tidak didaftarkan bukti perkawinan, perceraian dan anak yang di lahirk an di luar negeri akan menentukan status tentang kewarganegaraan dari anak tersebut terhadap hukum yang berlaku baik mengenai hukum publik maupun hukum perdata hal tersebut sebagaimana diatur dalam pasal 59 ayat 1 Undangundang No. 1 tahun 1974 tentang perkawinan yang berbunyi: "Kewarganegaraan yang diperoleh sebagai akibat perkawinan atau putusnya perkawinan menentukan hokum yang berlaku, baik mengenai hukum publik maupun mengenai hukum perdata; ${ }^{14}$

Pengaturan status dan kedudukan hukum anak dari hasil perkawinan campuran (beda kewarganegaraan) dalam undang-undang kewarganegaraan yang baru memberi perubahan yang positif, terutama dalam hubungan anak dengan ibunya, karena memberikan dwi-kewarganegaraan terbatas bagi anak dari hasil perkawinan campuran (beda kewarganegaraan). Pengaturan ini menimbulkan persoalan apabila di kemudian hari perkawinan orang tua putus, karena ibu akan kesulitan mendapatkan hak pengasuhan anaknya yang berkewarganegaraan asing. Dengan banyak terjadinya perkawinan campuran di Indonesia sudah seharusnya perlindungan hukum dalam perkawinan campuran ini diakomodir dengan baik dalam perundang-undangan di Indonesia. Hal tersebut seperti digambarkan pada kasus di bawah ini.

Bahwa SWITA MOTIRAM te lah meninggal dunia pada tangga 13 Nopember 2009, berdasarkan surat kematian No: AM. 500.0045343 yang dikeluarkan oleh Kantor Pencatatan sipil Kota administrasi Jakarta Pusat. Bahwa atas permohonan tersebut kemudian Tergugat mengeluarkan Surat Keterangan War is atas nama Para Penggugat sebagai ahli waris dari almarhumah SWITA MOTIRAM yaitu Surat Keterangan Hak Mewaris Nomor W7.AH.06.10- 08/II/ 2010 tanggal 25 Pebruari 2010 yang isinya menyatakan bahwa sebagai Ahli Waris dan berhak atas harta peninggalan almarhumah SWITA MOTIRAM adalah KAMLESH MOTIRAM KALWANI DAN JOHNY MOTIRAM.

Bahwa SUNESH RATTAN LADHARAM adalah sebagai Warga Negara asing maka tidak berhak memperoleh Hak milik di Indonesia hal tersebut sebagaimana diatur dalam Pasal 21 ayat 1 Undang- undang No. 5 tahun 1960 tentang UUPA yang berbunyi: "Hanya warga Negara Indones ia dapat mempunyai hak milik". Bahwa SUNESH RATTAN LADHARAM adalah sebagai seorang Warga Negara Asing bukan sebagai Warga Negara Indonesia oleh karena itu terhadapnya tidak bisa diberlakukan atas hukum waris yang berlaku di -

14 Halalam 8-10 Putusan No. 141/G/20 10/PTUN- JKT. 
66 Raden Ine Sri Indriani dkk, Kedudukan Harta Warisan Anak....

Indonesia. ${ }^{15}$

Pada contoh kasus di atas, maka jika anak yang terlahir dari hasil perkawinan campuran dan mempunyai kewarganegaraan ganda tersebut mewarisi harta dari kedua orang tuanya, maka akan menimbulkan permasalahan hukum, karena status anak tersebut sebagai warga Negara asing dan juga sebagai warga Negara Indonesia, di dalam ketentuan Undang-Undang No.5 Tahun 1960 tentang Peraturan Dasar Pokok-Pokok Agraria (UUPA) Pasal 21 ayat 3 menyatakan orang asing yang memperoleh hak milik karena pewarisan maka harus wajib melepaskan haknya itu dalam jangka waktu satu tahun sejak diperolehnya hak tersebut, jika haknya itu tidak dilepaskan, maka hak tersebut hapus karena hukum dan tanahnya jatuh pada Negara. ${ }^{16}$

Jika dalam perkawinan campuran si anak mewarisi harta warisan dari kedua orang tuanya, maka ketentuan UUPA Pasal 21 ayat 3 tersebut belum bisa dilaksanakan, mengingat adanya kewarganegaraan ganda dari anak tersebut. Bila anak hasil dari perkawinan campuran tersebut mewarisi dari harta orangtuanya dan hartanya tersebut ada dibawah pengawasan perwalian maka anak tersebut sudah dianggap sebagai warga Negara Indonesia, sehingga hal ini bertentangan dengan Undang-Undang No.12 Tahun 2006. Hal tersebut bisa menimbulkan persoalan baru yaitu siapakah yang akan memelihara dan menyimpan harta warisan anak tersebut sampai anak tersebut dewasa.
Berdasarkan latar belakang di atas, maka permasalahan dalam penulisan ini dapat dirumuskan, yaitu apakah anak yang dibawah umur yang memiliki kewarganegaraan ganda dapat menerima warisan dari orang tuanya yang melakukan perkawinan campuran?

Metode yang digunakan adalah penelitian yuridis normatif. Dikatakan demikian karena penelitian ini dilakukan untuk mengkaji kaidah-kaidah atau norma-norma dalam hukum positif. Pendekatan yang digunakan adalah pendekatan perundang-undangan (statute approach). pendekatan undang-undang dilakukan dengan menelaah semua undang-undang dan regulasi yang bersangkut-paut dengan masalah hukum yang sedang ditangani. ${ }^{17}$ Pendekatan Konseptual menurut Peter Mahmud Marzuki yaitu pendekatan konseptual beranjak dari pandanganpandangan dan doktrin-doktrin yang berkembang di dalam ilmu hukum, peneliti akan menemukan ide-ide yang melahirkan pengertian-pengertian hukum, konsep-konsep hukum, dan asas-asas hukum, dan asas- asas hukum relevan dengan isu yang dihadapi. Pemahaman akan pandangan-pandangan dan doktrin-doktrin tersebut merupakan sandaran bagi peneliti dalam membangun suatu argumentasi hukum dalam memecahkan isu yang dihadapi. ${ }^{18}$ Bagi penelitian untuk kegiatan praktis, pendekatan ini akan membuka kesempatan bagi peneliti untuk mempelajari adakah konsistensi dan kesesuaian antara suatu undang-undang dengan undangundang lainnya.

Halaman 11 Putusan No. 141/G/20 10/PTUN- JKT.

16 Undang-undang No.5 Tahun 1960 tentang Peraturan Dasar Pokok-pokok Agraria (UUPA).

17 Peter Mahmud Marzuki, Penelitian Hukum, Cetakan ke -11, Jakarta, Kencana, 2011, hal.93

18 Muhammad Fikri Podungge, Jenis-Jenis Penelitian di Bidang Keilmuan Hukum, fikripodungge.blogspot.com 


\section{Pembahasan}

Perkawinan campuran merupakan perkawinan antara dua orang yang di Indonesia tunduk pada hukum yang berlainan, karena perbedaan kewarganegaraan dan salah satu pihak berkewarganegaraan Asing dan salah satu pihak berkewarganegaraan Indonesia. Perkawinan campuran bukan merupakan suatu perkawinan antara dua orang yang berlainan agama atau hal lainnya, namun yang di maksud dengan perkawinan adalah perkawinan antara wanita dan laki-laki yang berbeda kewarganegaraannya. Mereka yang melakukan perkawinan campuran sesuai dengan pasal 57 UU No. 1 tahun 1974 apabila hendak melakukan perceraian maka tunduk pada UU No. 1 tahun 1974 dan PP No. 9 tahun 1975 untuk pengadilan negeri (bagi yang non muslim), dan ditambah dengan kompilasi hukum islam serta UU No. 7 tahun 1989 jo. UU No. 3 tahun 2006 tentang peradilan agama bila perkara diajukan melalui pengadilan agama (bagi yang muslim). Perceraian pada perkawinan campuran ini tentu berdampak pula pada status anak. Berdasarkan UU Kewarganegaraan yang lama yaitu UU No. 62 tahun 1958 bahwa anak hanya mengikuti kewarganegaraan ayahnya, namun berdasarkan UU Kewarganegaraan yang baru yaitu UU No. 12 tahun 2006 bahwa anak akan memiliki dua kewarganegaraan, dalam artian bisa mengikuti kewarganegaraan bapak atau ibunya. Namun setelah anak menginjak umur 18 tahun, maka anak tersebut bisa memilih sendiri kewarganegaraannya.

\subsection{Kewarganegaan Ganda Anak di Bawah Umur} dalam Perkawinan Campuran

Di Indonesia perkawinan campuran yang terjadi dapat dalam dua bentuk yaitu: Pertama, Wanita Warga Negara Indonesia (selanjutnya disebut WNI) yang menikah dengan pria Warga Negara Asing (selanjutnya disebut WNA); dan Kedua, Pria WNI menikah dengan wanita WNA. Faktor perbedaan kewarganegaraan di antara para pihaklah yang kemudian membedakan suatu perkawinan campuran dengan perkawinan yang bersifat intern. Perbedaan kewarganegaraan tersebut tidak saja terjadi saat awal dimulainya suatu perkawinan campuran, tetapi dapat berlanjut setelah terbentuknya suatu keluarga perkawinan campuran. Perkawinan campuran dapat dilaksanakan di Indonesia dan dapat pula dilaksanakan di luar Indonesia (luar negeri). Apabila dilangsungkan di Indonesia, maka perkawinan campuran dilaksanakan menurut UU Perkawinan, serta syaratsyarat untuk melaksanakan perkawinan campuran harus dipenuhi, syarat-syarat perkawinan yang berlaku menurut hukum masing-masing pihak (Pasal 60 ayat (1) UU Perkawinan). ${ }^{19}$ Perkawinan yang dilangsungkan di luar Indonesia antara dua orang warga Negara Indonesia atau seorang warga Negara Indonesia dengan warga Negara asing adalah sah bilamana dilakukan menurut hukum yang berlaku di Negara dimana perkawinan itu dilangsungkan dan bagi warga Negara Indonesia tidak melanggar ketentuan UU Perkawinan. ${ }^{20}$

\footnotetext{
19 Abdulkadir Muhammad, Hukum Perdata Indonesia, Citra Aditya Bakti, Bandung, 2014, hlm. 114.

20 Hilman Hadikusuma, Hukum Perkawinan Indonesia Menurut Perundangan, Hukum Adat, Hukum Agama, Mandar Maju, Bandung, 1990, hIm. 20.
} 


\section{Raden Ine Sri Indriani dkk, Kedudukan Harta Warisan Anak...}

Perkawinan campuran dianggap sah, apabila hal itu dilangsungkan di Indonesia sendiri maupun di luar negeri berdasarkan ketentuan yang berlaku di negara tersebut. Apabila perkawinan tersebut dilakukan di luar negeri, maka setelah mereka kembali ke Indonesia harus melaporkan perkawinan tersebut kepada Kantor Pencatatan Perkawinan. Hal ini ini seperti yang dijelaskan pada petikan Putusan Mahkamah Agung di bawah ini.

Bahwa apabila kita telaah dengan cermat Pasal 56 Ayat (1) dan (2) UU Perkawinan, secara lengkap berbunyi sebagai berikut:

(1) Perkawinan di Indonesia antara dua orang warganegara Indonesia atau seorang warganegara Indonesia dengan warganegara Asing adalah sah bilamana dilakukan menurut hukum yang berlaku di negara dimana perkawinan itu dilangsungkan dan bagi warganegara Indonesia tidak melanggar ketentuan Undang- undang ini.

(2) Dalam waktu 1 (satu) tahun setelah suami istri itu kembali di wilayah Indonesia, surat bukti perkawinan mereka harus didaftarkan di Kantor Pencatatan Perkawinan tempat tinggal mereka". ${ }^{21}$

Selama para pihak telah melaksanakan pencatatan perkawinan di luar negeri sesuai hukum yang berlaku di Negara tempat perkawinan tersebut dilangsungkan, maka perkawinan adalah sah dengan segala akibat hukumnya. Akibat hukum disini meliputi status anak, harta perkawinan, pewarisan, hak dan kewajiban suami-istri jika perkawinan berakhir karena perceraian, dan atau sebagainya. Namun, untuk sahnya perkawinan yang dilangsungkan di luar negeri tersebut menurut hukum Indonesia harus dilakukan pencatatan dan pelaporan pada Dinas Kependudukan dan Catatan Sipil di Indonesia dalam kurun waktu 1 (satu) tahun. 22

$$
\text { Undang-Undang Kewarganegaraan }
$$

Indonesia No. 62 Tahun 1958 (yang selanjutnya disebut UU Kewarganegaraan Lama) menganut asas kewarganegaraan tunggal. Dimana kewarganegaraan anak yang lahir hasil perkawinan campuran mengikuti kewarganegaraan ayahnya sesuai Pasal 13 ayat 1 yang menyatakan:
"Anak yang belum berumur 18 tahun dan belum kawin yang mempunyai hubungan hukum kekeluargaan dengan ayahnya sebelum ayah itu memperoleh kewarganegaraan Republik Indonesia, turut memperoleh kewarganegaraan Republik Indonesia setelah ia bermukim dan berada di Indonesia. Keterangan mengenai bertempat tinggal dan berada di Indonesia tidak berlaku terhadap anak- anak yang ayahnya memperoleh kewarganegaraan Republik Indonesia menjadi tanpa kewarganegaraan."

\section{Berdasarkan ketentuan}

UU

Kewarganegaraan Lama, anak yang lahir dari perkawinan campuran bisa menjadi WNI dan bisa menjadi WNA. Bila seorang anak lahir dari perkawinan antara seorang wanita WNA dengan pria WNI, sesuai Pasal 1 huruf b UU Kewarganegaraan Lama, kewarganegaraan anak mengikuti ayahnya, yaitu anak menjadi WNI, bila ibu dapat memberikan kewarganegaraannya kepada si anak maka anak tersebut kehilangan kewarganegaraan Indonesia. Sebaliknya bila anak yang lahir dalam perkawinan -

21 Halaman 32 Putusan No. 141/G/20 10/PTUN-JKT

22 Irma Devita Purnamasari, Kiat-kiat Cerdas, Mudah dan Bijak Memahami Masalah Hukum Waris, Mizan Pustaka, Bandung, 2014, hlm. 157. 
antara wanita WNI dan pria WNA, maka anak menjadi WNA mengikuti ayahnya.

Bilamana anak tersebut lahir serta bermukim di Indonesia, maka terhadap anak tersebut harus dibuatkan paspor di Kedutaan Besar ayahnya serta harus mendapat Kartu Izin Tinggal Sementara (KITAS) yang harus terus diperpanjang serta memerlukan biaya yang mahal.

Setelah diundangkan Undang-Undang Kewarganegaraan Indonesia No. 12 Tahun 2006 (yang selanjutnya disebut UU Kewarganegaraan Baru) pada tanggal 1 Agustus Tahun 2006 yang menggantikan UU Kewarganegaraan Lama memberikan angin segar bagi para pelaku perkawinan campuran, karena anak-anak yang lahir dari suatu perkawinan campuran tetap diakui sebagai WNI di samping kewarganegaraan asingnya yang mengikuti ayahnya atau dengan kata lain anak-anak hasil perkawinan campuran dapat memperoleh kewarganegaraan ganda.

Dalam Pasal 4 huruf $c \quad$ UU Kewarganegaraan Baru menyatakan: "Warga Negara Indonesia adalah: anak yang lahir dari perkawinan yang sah dari seorang ayah Warga Negara Indonesia dan Ibu Warga Negara Asing. Selanjutnya, Pasal 4 huruf d menyatakan: 'Warga Negara Indonesia adalah anak yang lahir dari perkawinan yang sah dari seorang ayah Warga Negara Asing dan ibu Warga Negara Indonesia.

Pada Pasal 6 ayat 1 menyatakan: "Dalam hal status Kewarganegaraan Republik Indonesia terhadap anak sebagaimana dimaksud dalam Pasal 4 huruf $c$, huruf $d$, huruf $h$, huruf $i$ dan Pasal 5 berakibat anak berkewarganegaraan ganda, setelah 18 (delapan belas) tahun atau sudah kawin anak tersebut harus menyatakan memilih salah satu kewarganegaraannya"

Pasal 6 ayat 1 UU Kewarganegaraan Baru tersebut di atas maka kewarganegaraan ganda anak dalam suatu perkawinan campuran bersifat terbatas sampai pada usia 18 tahun saja, kemudian dia diberi waktu 3 tahun untuk memilih apakah akan menjadi WNI atau WNA.

Dalam Pasal 47 ayat 1 UUP, juga ditegaskan batasan usia seorang anak adalah 18 tahun. Pasal tersebut menyatakan" Anak yang belum mencapai umur 18 (delapan belas) tahun atau belum pernah melangsungkan perkawinan ada di bawah kekuasaan orangtuanya, selama mereka tidak atau belum dicabut dari kekuasaannya". Sejalan dengan adanya ketentuan usia 18 tahun bagi seorang anak, Undang-Undang No. 23 Tahun 2002 tentang Perlindungan Anak lebih jelas memberikan definisi tentang anak yang diatur dalam Pasal 1 angka 1 sebagai berikut: "Anak adalah seseorang yang belum genap berusia 18 (delapan belas) tahun termasuk anak yang masih dalam kandungan".

Berdasarkan ketentuan-ketentuan tersebut di atas, kesimpulan yang dapat ditarik bahwa batas usia seseorang yang dianggap sebagai anak di bawah umur di Indonesia adalah 18 (delapan belas) tahun atau sudah kawin. Undang-Undang kewarganegaraan yang baru memuat asas-asas kewarganegaraan umum atau universal.

23 Abdulkadir Muhammad, Hukum Perdata Indonesia, Citra Aditya Bakti, Bandung, 2014, hlm. 114.

24 Hilman Hadikusuma, Hukum Perkawinan Indonesia Menurut Perundangan, Hukum Adat, Hukum Agama, Mandar Maju, Bandung, 1990, hlm. 20. 
70 Raden Ine Sri Indriani dkk, Kedudukan Harta Warisan Anak....

Adapun asas-asas yang dianut dalam Undang-Undang ini sebagai berikut:

a. Asas ius sanguinis (law of the blood) adalah asas yang menentukan kewarganegaraan seseorang berdasarkan keturunan, bukan berdasarkan negara tempat kelahiran.

b. Asas ius soli (law of the soil) secara terbatas adalah asas yang menentukan kewarganegaraan seseorang berdasarkan negara tempat kelahiran, yang diberlakukan terbatas bagi anak-anak sesuai dengan ketentuan yang diatur dalam Undang-Undang ini.

c. Asas kewarganegaraan tunggal adalah asas yang menentukan satu kewarganegaraan bagi setiap orang.

d. Asas kewarganegaraan ganda terbatas adalah asas yang menentukan kewarganegaraan ganda bagi anak-anak sesuai dengan ketentuan yang diatur dalam Undang-Undang ini.

Undang-Undang ini pada dasarnya tidak mengenal kewarganegaraan ganda (bipatride) ataupun tanpa kewarganegaraan (apatride). Kewarganegaraan ganda yang diberikan kepada anak dalam Undang-Undang ini merupakan suatu pengecualian. ${ }^{23}$

Anak-anak yang lahir sebelum UndangUndang ini diundangkan, mereka dapat memperoleh kewarganegaraan ganda atau dapat menjadi WNA. Mereka dapat memperoleh kewarganegaraan ganda, bila orangtua atau walinya mendaftarkan mereka kepada Menteri melalui Pejabat atau Perwakilan Republik Indonesia paling lambat 4 (empat) tahun setelah Undang-Undang ini diundangkan. Dengan didaftarkannya anak-anak tersebut, maka mereka memperoleh Surat Keputusan dari Menteri Hukum dan HAM bahwa mereka adalah WNI. Bila sampai dengan Tahun 2010 anak-anak tersebut tidak didaftarkan maka mereka dianggap sebagai WNA sesuai Pasal 41 UU No. 12 Tahun 2006 jo. Permen Hukum dan HAM No. M.01-HL.03.01 Tahun 2006 tentang Tata Cara Pendaftaran Anak untuk memperoleh Kewarganegaraan RI. Sedangkan anak-anak yang lahir di Indonesia setelah UndangUndang ini diundangkan, pencatatan dilakukan pada Kantor Kependudukan dan Catatan Sipil dan memperoleh akte kelahiran sebagai WNI.

Undang-Undang Kewarganegaraan Lama maupun Undang-Undang Kewarganegaraan Baru tidak memberikan status kewarganegaraan Indonesia secara otomatis bagi wanita WNA yang menikah dengan pria WNI, tetapi apabila wanita WNA tersebut ingin menjadi WNI maka ia harus mengajukan permohonan resmi sesuai peraturan yang berlaku. Demikian juga wanita WNI yang menikah dengan seorang pria WNA dapat tetap mempertahankan kewarganegaraan Indonesia, bila ia hendak mengikuti kewarganegaraan suami menjadi WNA, maka wanita tersebut diharuskan untuk mengajukan permohonan sesuai peraturan yang berlaku seperti tertuang dalam Pasal 7 dan 8 UU Kewarganegaraan Lama, dan Pasal 26 UU Kewarganegaraan Baru. Hal yang demikian itu dapat menimbulkan perbedaan kewarganegaraan dalam keluarga suatu perkawinan campuran.

Perbedaan kewarganegaraan tidak saja terjadi antara pasangan suami istri dalam suatu perkawinan campuran, tetapi juga terjadi pada anak-

25 Penjelasan Undang-Undang Republik Indonesia Nomor 12 Tahun 2006 Tentang Kewarganegaraan Republik Indonesia. 
anak hasil perkawinan campuran. Menurut UU Kewarganegaraan Lama, kewarganegaraan untuk anak hasil perkawinan campuran mengikuti kewarganegaraan ayahnya, apabila anak yang lahir dalam suatu perkawinan campuran dari ibu WNI dan ayahnya WNA, anak tersebut secara otomatis menjadi WNA, sehingga terjadi perbedaan kewarganegaraan antara anak yang lahir tersebut dengan ibunya yang WNI.

Perbedaan kewarganegaraan antara anak WNA dengan ibunya WNI menimbulkan banyak masalah hukum, baik selama masa perkawinan campuran itu berlangsung maupun setelah putusnya perkawinan campuran. Terdapat banyak kasus yang muncul, dimana UU Kewarganegaraan Lama tidak dapat melindungi anak-anak yang lahir dari seorang ibu WNI suatu perkawinan campuran, teristimewa saat putusnya perkawinan dan anaknya yang WNA harus berada dalam pengasuhan ibunya WNI serta bertempat tinggal di dalam Negara Indonesia yang notabene merupakan negara ibunya sendiri.

Dengan diundangkannya UU Kewarganegaraan Baru, aturan ini memberikan kewarganegaraan ganda, hanya terbatas pada anakanak hasil perkawinan campuran sampai anak tersebut berusia 18 tahun atau sudah kawin, setelah itu ia harus memilih salah satu untuk menjadi kewarganegaraannya. Adapun status kewarganegaraan ganda yang dianut dalam UU Kewarganegaraan Baru merupakan terobosan untuk mengatasi permasalahan yang timbul dalam perkawinan campuran, maupun setelah putusnya perkawinan campuran, dimana terdapat perbedaan kewarganegaraan antara orangtua dan anak-anak hasil perkawinan itu.

$$
\text { Seiring dengan melekatnya }
$$

kewarganegaraan ganda terbatas pada anak hasil perkawinan campuran, maka anak tersebut tunduk pada dua yurisdiksi dari dua negara yang terkait kewarganegaraan dari kedua orangtuanya, sehingga menimbulkan permasalahan hukum di bidang Hukum Perdata Internasional, yaitu hukum dari negara mana yang berlaku atas status personalnya. Kedudukan anak yang belum berumur 18 tahun dan belum kawin akan mengikuti kewarganegaraan ayah atau ibunya dengan siapa ia mempunyai hubungan hukum keluarga. ${ }^{24}$ Pasal 6 ayat (1) UU Kewarganegaraan RI yang baru. Menyebutkan bahwa anak tersebut akan berkewarganegaraan ganda, dan setelah anak berusia 18 tahun atau sudah kawin maka ia harus menentukan pilihannya.

\subsection{Hak Waris Anak di Bawah Umur yang Dilahirkan dalam Perkawinan Campuran}

Hukum Perdata Internasional adalah seperangkat kaidah-kaidah, asas-asas, dan atau aturan-aturan hukum nasional yang dibuat untuk mengatur peristiwa atau hubungan hukum yang mengandung unsur-unsur transnasional (atau unsurunsur ekstrateritorial). ${ }^{25}$ Maka dari itu persoalan yang terkait unsur asing dapat terselesaikan dengan menggunakan Asas- Asas Hukum Perdata Internasional. Secara teori, dalam Hukum Perdata Internasional dikenal dua pandangan utama yang berusaha membatasi pengertian perkawinan campuran, yaitu: Pandangan yang beranggapan bahwa suatu perkawinan campuran adalah perka-

\footnotetext{
26 Harumiati Natadimaja, Hukum Perdata Mengenai Hukum Perorangan dan Hukum Benda, Graha Ilmu, Jakarta, 2009, hal. 38.

27 Bayu Seto Hardjowahono, Dasar-Dasar Hukum Per

28 data Internasional, Citra Aditya Bakti, Bandung, 2006, hlm. 11.
} 


\section{Raden Ine Sri Indriani dkk, Kedudukan Harta Warisan Anak...}

winan yang berlangsung antara pihak-pihak yang berbeda domisilinya sehingga terhadap masingmasing pihak berlaku kaidahkaidah hukum yang berbeda, dan pandangan yang beranggapan bahwa suatu perkawinan dianggap sebagai perkawinan campuran apabila para pihak berbeda nasionalitasnya. ${ }^{27}$

Sesuai dengan asas dalam Hukum Perdata Internasional tentang hukum yang harus digunakan untuk mengatur suatu perkawinan adalah asas yang menyatakan bahwa validitas materiil perkawinan harus ditentukan berdasarkan sistem hukum dari tempat masing-masing pihak berdomisili sebelum perkawinan diadakan. ${ }^{28}$

Dalam Hukum Perdata, manusia memiliki status sebagai subjek hukum sejak ia dilahirkan, kecuali apa yang diatur dalam Pasal 2 BW bahwa anak yang masih berada dalam kandungan dapat menjadi subjek hukum bila ada kepentingan yang menghendaki dan dilahirkan dalam keadaan hidup. Manusia sebagai subjek hukum berarti manusia memiliki hak dan kewajiban dalam lalu lintas hukum, namun untuk anak sebagai pendukung hak dan kewajiban, selama anak tersebut belum dewasa atau belum kawin, pada umumnya anak hanya mempunyai hak dan belum mempunyai kewajiban, sehingga mereka lebih banyak mendapat keuntungan akibat kewarganegaraan ganda. Oleh sebab itu bila mereka telah dewasa atau sudah kawin mereka harus memilih salah satu di antara kewarganegaraan ganda tersebut. Bila mereka tidak memilih salah satu dari kedua kewarganegaraannya maka mereka dianggap sebagai orang asing.
Status atau identitas kewarganegaraan sangat penting karena status itu merupakan tanda dalam sebuah hubungan hukum antara perorangan dengan negara. Status tersebut menjadi dasar hukum penyelenggaraan hak dan kewajiban sipil sebagai warga negara, dimana identitas warganegara mempunyai implikasi pada hak dan kewajiban sebagai warga begara yang diatur dalam hukum tentang kewarganegaraan. ${ }^{29}$

Berkaitan dengan status anak yang berkewarganegaraan ganda yaitu mengenai warisan yang ditinggalkan ayah atau ibunya yang berkewarganegaraan Indonesia. Menurut teori Hukum Perdata Internasional untuk menentukan status anak dan hubungan antara anak dan orangtua perlu dilihat lebih dahulu. Perkawinan orangtuanya sebagai persoalan pendahuluan, apakah perkawinan orangtuanya sah, bila anak lahir dalam suatu perkawinan yang sah maka bila salah satu atau kedua orangtuanya meninggal maka anak adalah ahi waris. Bila perkawinan orangtuanya sah, sehingga anak memiliki hubungan hukum dengan ayahnya, dan bila perkawinan orangtuanya tidak sah, maka anak hanya mempunyai hubungan hukum dengan ibunya.

Bagir Manan berpendapat bahwa akta nikah dan pencatatan perkawinan bukan satu-satunya alat bukti mengenai adanya perkawinan atau keabsahan perkawinan, karena akta nikah dan pencatatan nikah adalah sebagai alat bukti tetapi bukan alat bukti yang menentukan. Pencatatan sesuai dengan penjelasan Pasal 2 ayat (2), dipandang sebagai suatu peristiwa penting, bukan suatu peristiwa hukum, karena -

29 Ibid., hlm. 12.

30 Sudargo Gautama, Hukum Perdata Internasional Indonesia, Jilid III Bagian I Buku ke-7, Penerbit Alumni, Bandung, 1995, hlm. 189.

31 Harumiati Nuning Himlet, Perempuan dan Kewarganegaraan Perempuan dan Hukum, Menuju Hukum yang Berspektif Kesetaraan dan Keadilan, Yayasan Obor Indonesia, Jakarta, 2008, hlm. 402. 
perkawinan sebagai peristiwa hukum ditentukan oleh agama, maka pencatatan tidak akan mempunyai akibat hukum apalagi mengesampingkan sahnya perkawinan yang telah memenuhi syarat masingmasing agama. ${ }^{30}$ Akibat hukum tidak dicatatnya perkawinan antara lain:

a. Perkawinan dianggap tidak sah Meskipun perkawinan dilakukan menurut Agama dan kepercayaan, namun dimata negara perkawinan tersebut dianggap tidak sah jika belum dicatat oleh Kantor Urusan Agama (KUA) atau Kantor Catatan Sipil.

b. Anak hanya mempunyai hubungan perdata dengan ibu dan keluarga ibu Anak-anak yang dilahirkan diluar perkawinan atau perkawinan yang tidak tercatat, selain dianggap anak tidak sah, juga hanya mempunyai hubungan perdata dengan Ibu atau keluarga Ibu (Pasal 42 dan 43 Undang Undang Perkawinan). Pasa1 42 :"Anak yang sah adalah anak yang dilahirkan dalam atau sebagai akibat perkawinan yang sah". Pasa1 43 meneyebutkan: (1) Anak yang dilahirkan di luar perkawinan hanya mempunyai hubungan perdata dengan ibunya dan keluarga ibunya.; (2) Kedudukan anak tersebut ayat (1) di atas selanjutnya akan diatur dalam Peraturan Pemerintah".

c. Anak dan ibunya tidak berhak atas nafkah dan warisan Akibat lebih jauh dari perkawinan yang tidak dicatat adalah baik istri maupun anak-anak yang dilahirkan dari perkawinan tersebut tidak berhak menuntut nafkah ataupun warisan dari ayahnya.
Mengenai status hukum berkaitan dengan perlindungan anak dari hasil perkawinan campuran yang lahir di Negara Indonesia dan pengaturan perlindungan hukum, mengingat perkawinan campuran sendiri sudah menimbulkan konsekunesi yang berbeda dengan perundang-undangan yang terdahulu, apalagi perkawinan campuran tersebut tidak dicatatkan. Pengertian anak menunjukkan adanya bapak dan ibu dari anak itu, dalam arti bahwa sebagai hasil dari seorang pria dan seorang wanita, maka wanita tersebut melahirkan manusia lain yang dapat menyatakan bahwa seorang pria adalah ayahnya dan seorang wanita adalah ibunya. ${ }^{31}$

Bilamana anak yang berkewarganegaraan ganda memperoleh warisan dari salah satu orangtuanya berupa tanah hak milik, maka hak anak tersebut tentunya tidak hapus. Akan tetapi ia harus menunggu sampai usianya mencapai 18 (delapan belas) tahun, kemudian memilih menjadi WNI barulah ia dapat memiliki haknya sesuai peraturan yang berlaku.

Berkaitan dengan permasalahan hak waris anak yang lahir dari perkawinan campuran terhadap hak milik atas tanah, maka Edithafitri dalam laporan penelitian menyarankan:32 (1) Bagi anak yang lahir dari perkawinan campuran untuk mendapatkan hak milik atas tanah yang ada di Indonesia sebaiknya pada saat usia 18 (delapan belas) tahun atau sudah kawin untuk segera menyatakan menjadi warga negara Indonesia yang disampaikan kepada pejabat atau perwakilan Republik Indonesia yang wilayah kerjanya meliputi tempat tinggal dimana anak ter-

32 Neng Djubaidah, Pencatatan perkawinan dan Perkawinan Tidak Dicatat Menurut Hukum Tertulis di Indonesia dan Hukum Islam, Sinar Grafika, Jakarta, 2012, hlm. 158.

33 Wirjono Prodjodikoro, Hukum Perkawinan di Indonesia, Sumur Bandung, Bandung, 1994, hlm. 72.

34 Rahmadika Safira Edithafitri, "Hak Waris Anak Yang Lahir Dari Perkawinan Campuran Terhadap Hak Milik Atas Tanah", Lex Administratum, Vol. V/No. 7/Sep/2017, hlm. 34 


\section{Raden Ine Sri Indriani dkk, Kedudukan Harta Warisan Anak....}

-sebut berada. Namun apabila menyatakan memilih warga negara asing maka maka anak tersebut wajib melepaskan hak milik tersebut dalam jangka waktu 1 (satu) tahun sejak hak tersebut diperoleh; (2) Bagi warga negara Indonesia yang akan melakukan perkawinan campuran sebaiknya membuat perjanjian perkawinan yang disahkan pegawai pencatat perkawinan mengenai pemisahan harta sama sekali, yaitu harta yang diperoleh selama perkawinan dimiliki masing-masing, serta hak dan kewajiban yang diperoleh sebelum atau setelah perkawinan menjadi tanggung jawab masingmasing. Dengan adanya perjanjian perkawinan maka harta asal suami dan istri tetap terpisah dan tidak terbentuk harta bersama. Sehingga bagi warga negara Indonesia masih memiliki kesempatan untuk memiliki hak atas tanah yang kepemilikannya terpisah dari pasangannya yang merupakan warga negara asing.

Berdasarkan ketentuan di atas, maka hakhak anak seperti hak waris anak yang berwarganegara asing tidak dapat diberikan, karena terikat oleh ketentuan hukum nasional Indonesia, seperti UUPA, walaupun atas pertimbangan tertentu hal tersebut kurang adil dan tidak memberikan perlindungan kepada anak.

Hak-hak Anak dalam Undang-undang nomor 39 tahun 1999 tentang Hak Asasi Manusia, Hak asasi manusia sejarahnya lebih jauh lagi yaitu sejak ada manusia dan kemanusiaan, dengan kata lain sejak perkembagan manusia itu sendiri. Hak asasi manusia telah melekat pada seseorang sejak ia dilahirkan dan bahkan mungkin sejak dalam kandugan telah memiliki hak asasi apabila dilihat dari segi hukum. Undang-Undang Nomor 39 Tahun 1999 tentang HAM dalam Pasal 52 ayat (2) menyatakan: Hak anak adalah hak asasi manusia dan untuk kepentingannya hak anak itu diakui dan dilindungi oleh hukum bahkan sejak dalam kandungan.

Berdasarkan yurisprudensi dalam Hukum Perdata Internasional baik di Belanda maupun di Indonesia, hukum yang berlaku mengenai warisan adalah hukum nasional dari pewaris. Terkait kewarganegaraan ganda anak dari hasil perkawinan campuran, bila salah satu orangtuanya yaitu ibunya WNI atau ayahnya WNI meninggal dunia, tentunya anak-anaknya adalah ahli waris ibu atau ayahnya yang adalah WNI. Hal tersebut seperti terungkap dalam petikan Putusan Mahkamah Agung berikut ini.

Bahwa berdasarkan Pasal 852 Kitab Undang- undang Hukum Perdata (KUHPer), berbunyi sebagai berikut: "Anak- anak ataupun sekalian keturunan mereka, biar dilahirkan dari lainlain perkawinan sekalipun, mewaris dari kedua orang tua, kakek, nenek atau semua keluarga sedarah mereka selanjutnya dalam garis lurus ke atas, dengan tiada perbedaan antara laki-laki atau perempuan dan tiada perbedaan kelahiran lebih dahulu."

Bahwa berdasarkan ketentuan dimaksud sangat jelas mengatur bahwa anak-anak/keturunan, sekalipun dilahirkan dari lain-lain perkawinan, mewaris dari kedua orang tuanya. Ketentuan dimaksud tidak melihat/mengatur mengenai status - 
kewarganegaraan seorang anak untuk dapat mewaris dari kedua orang tuanya. Artinya, apapun warga negara si anak/keturunan tidak dapat menghalangi/menghapus hak mewaris si anak/keturunan dari kedua orang tuanya. Sehingga dalam hal ini walaupun Sdr. SUNESH RATTAN LADHARAM berstatus sebagai Warga Negara Asing (WNA) adalah tetap merupakan ahli waris yang sah dari almarhumah nyonya SWITA MOTIRAM alias SIWITA RATTAN LADHARAM, dikarenakan ia merupakan anak/keturunan yang sah dari almarhumah nyonya SWITA MOTIRAM al ias SIWITA RATTAN LADHARAM sebagaimana terbukti pada Akta Kelahiran Sdr. SUNESH RATTAN LADHARAM yang telah dilegalisir oleh Kedutaan Besar Republik Indonesia No. Z027512 2DI tertanggal 21 Agustus 1982 (Bukti T- 7), yang sangat jelas menyebutkan bahwa Sdr. SUNESH RATTAN LADHARAM adalah seorang anak yang dilahirkan dalam perkawinan pasangan suami isteri SWITA MOTIRAM dengan RATTAN LADHARAM. ${ }^{33}$

Peralihan hak atas tanah dari pemegang haknya kepada pihak lain dapat terjadi karena peristiwa hukum, yaitu meninggal dunianya pemegang hak atas tanah, disini peralihan haknya terjadi melalui pewarisan, atau karena suatu perbuatan hukum yang dilakukan oleh pemegang hak atas tanah dengan pihak lain, yaitu berupa jual beli, tukar-menukar, hibah, pemasukan dalam modal perusahaan, dan lelang. Yang dimaksud pewarisan hak adalah berpindahnya hak atas tanah dari pemegang haknya meninggal dunia. Dengan meninggal dunianya pemegang hak atas tanah tersebut berpindah kepada ahli warisnya. Jatuhnya harta warisan dari pemegang hak atas tanah kepada ahli waris bukan karena suatu perbuatan hukum, melainkan berpindah karena peristiwa hukum. ${ }^{34}$

Namun demikian, di Indonesia seseorang yang berstatus WNA dibatasi untuk memperoleh hak-hak tertentu, seperti yang diatur dalam UndangUndang Pokok Agraria No. 5 Tahun 1960 (yang selanjutnya disebut UUPA), dalam Pasal 21 ayat 2 dikatakan orang asing tidak dapat mempunyai hak milik, pada ayat 3 juga melarang seorang yang mempunyai kewarganegaraan ganda mempunyai hak milik. Sedangkan terhadap Hak Guna Bangunan, sesuai Pasal 36 UUPA jo. Pasal 19 PP No. 40 Tahun 1996, disebutkan bahwa hak guna bangunan hanya diberikan kepada WNI. Hak-hak atas tanah yang dapat dimiliki oleh WNA hanya hak pakai.

Walaupun demikian, warga negara asing dapat mewarisi harta peninggalan orang tua, hanya saja setelah harta tersebut diwarisi, maka dalam jangka waktu sebelum 1 tahun harta tersebut harus dilepaskan kepada pihak lain, seperti menjual hak milik tersebut. Hal ini seperti dijelaskan pada Putusan Mahkamah Agung berikut ini.

Bahwa berdasarkan Pasal 21 ayat 3 Undang Undang No. 5 tahun 1960 tentang Undang Undang Pokok Agraria (UUPA), pada pokoknya mengatur bahwa orang asing yang sesudah berlakunya Undang-undang ini memperoleh hak milik karena pewarisan-tanpa- wasiat atau percampuran harta karena perkawinan, wajib melepaskan hak itu dalam jangka waktu satu tahun sejak diperolehnya hak tersebut. Bahwa berdasarkan aturan dimaksud, artiya Saudara -

35 Pembelaan Kuasa Hukum Tergugat II Intervensi pada halaman 20-21 Putusan No. 141/G/20 10/PTUN-JKT

36 Urip Santoso, Op.Cit., hIm. 398. 


\section{Raden Ine Sri Indriani dkk, Kedudukan Harta Warisan Anak...}

SUNESH RATTAN LADHARAM sebagai Warga

Negara Asing dapat mewaris-tanpa wasiat, namun ia dalam jangka waktu 1 (satu) tahun harus melepaskan hak itu. Pelepasan hak dapat dilakukan dengan menjual hak milik yang diperolehnya kepada pihak lain. ${ }^{35}$

Bila undang-undang di Indonesia membatasi hak-hak seseorang yang mempunyai kewarganegaraan ganda, dan pada sisi lain UU Kewarganegaraan Baru mengakui keberadaan seorang anak dengan status kewarganegaraan ganda. Setelah diundangkannya UU Kewarganegaraan Baru, peraturan di bidang agraria belum berubah, sehingga anak-anak yang berkewarganegaraan ganda sulit untuk merealisasikan haknya, dalam arti memiliki hak-hak atas tanah yang ditinggalkan oleh salah satu orangtuanya yang berkewarganegaraan Indonesia.

Perkawinan campuran telah menimbulkan beberapa permasalahan, salah satunya mengenai hak mewaris anak yang lahir dari perkawinan tersebut. Proses pemilikan atau peralihan hak atas tanah yang diperoleh secara warisan paling sering menjadi masalah pelik di kalangan masyarakat. Tentu saja, jika dikaitkan dengan warisan atas tanah yang diperoleh secara turun-temurun. ${ }^{36}$

Meskipun menurut hukum setiap manusia adalah pembawa hak tanpa terkecuali, namun ada pembatasan-pembatasan. Yang membatasi kecakapan berhak dalam hal ini yaitu Kewarganegaraan, hanya Warga Negara Indonesia yang dapat mempunyai hak milik (Pasal 21 ayat (1) UUPA). ${ }^{37}$
Dengan adanya Putusan Mahkamah Konstitusi Nomor 69/PUUXIII/2015 telah memperlonggar makna perjanjian perkawinan. Dengan putusan MK tersebut, kini perjanjian tak lagi bermakna perjanjian yang dibuat sebelum perkawinan (prenuptial agreement) tetapi juga bisa dibuat setelah perkawinan berlangsung. Aturan dalam kedua Undang-undang yang digugat di Mahkamah Konstitusi tersebut dinilai diskriminatif lantaran mereka yang melakukan perkawinan campuran dengan warga negara asing tidak bisa memperoleh hak milik dan hak guna bangunan. Pasal 29 ayat 1 UU Perkawinan, pada waktu sebelum dilangsungkan atau selama dalam ikatan perkawinan kedua belah pihak atas persetujuan bersama dapat mengajukan perjanjian tertulis yang disahkan oleh pegawai pencatat perkawinan atau notaris, setelah mana isinya berlaku juga terhadap pihak ketiga sepanjang pihak ketiga tersangkut.

Dengan adanya Putusan Mahkamah Konstitusi Nomor 69/PUUXIII/2015, sebaiknya bagi pasangan yang melakukan perkawinan campuran segera membuat perjanjian perkawinan yang mana dalam hal ini akan mempermudah bagi pasangan warga negara indonesia untuk memilik baik tanah dan bangunan dengan status hak milik sehingga tanah dan bangunan tersebut dapat diwariskan kepada anak yang lahir dari perkawinan campuran tersebut mengingat ketentuan bahwa anak tersebut telah memilih menjadi warga negara Indonesia.

Warga Negara Indonesia yang melakukan perkawinan campuran dibolehkan memiliki hak milik, hak guna bangunan dengan catatan bahwa -

37 Pembelaan Kuasa Hukum Tergugat II Intervensi pada halaman 22-23 Putusan No. 141/G/20 10/PTUN-JKT

38 Irma Devita Purnamasari, Op.cit., hlm. 173

39 Djaja S. Meiliala, Hukum Perdata Dalam Perspektif BW, Nuansa Aulia, Bandung, 2013, hlm. 21. 
para pihak dalam perkawinan campuran tersebut membuat perjanjian perkawinan sebelum menikah. ${ }^{38}$ Seorang WNI yang menikah secara sah dengan WNA, di mana WNA tersebut memperoleh asset berupa tanah dengan status hak milik, hak guna bangunan, hak guna usaha, hak milik atas satuan rumah susun di atas tanah, baik karena pewarisan, peralihan hak melalui jual beli, hibah atau wasiat, maka dia wajib melepaskan hak-haknya dalam jangka waktu satu tahun sejak diperolehnya hak-hak tersebut (Ketentuan Pasal 21 ayat (3) Undang-Undang No. 5 Tahun 1960 tentang Peraturan Dasar Pokok pokok Agraria). Pasal 27 ayat 2 menjelaskan, setiap jual beli, penukaran, penghibahan, pemberian dengan wasiat dan perbuatan-perbuatan lain yang dimaksudkan untuk langsung atau tidak langsung memindahkan hak milik kepada orang asing, kepada seorang warga negara yang di samping kewarganegaraan Indonesianya mempunyai kewarganegaraan asing atau kepada suatu badan hukum kecuali yang ditetapkan oleh Pemerintah termaksud dalam pasal 21 ayat 2 , adalah batal karena hukum dan tanahnya jatuh kepada Negara, dengan ketentuan, bahwa hak-hak pihak lain yang membebaninya tetap berlangsung serta semua pembayaran yang telah diterima oleh pemilik tidak dapat dituntut kembali. ${ }^{39}$

Menurut Wirjono Prodjodikoro, perkawinan campuran masih terdapat unsur nasional dan unsur asing. Unsur nasional adalah peraturan pihak yang berkewarganegaraan Indonesia, serta unsur asing ialah peraturan dari suatu negara asing. ${ }^{40}$ Menurut
J.C.T Simorangkir dan Woerjono Sastropranoto, perkawinan campuran yang melibatkan status kewarganegaraan para pihak, pada dasarnya menyangkut dua bidang hukum, yaitu bidang hukum perkawinan (huwelijksrecht) dan bidang hukum kewarganegaraan (nationaliteitsrecht). Kewarganegaraan merupakan suatu masalah yang sangat penting bagi hidup seseorang karena menyangkut kehidupan sehari-hari seseorang dalam lapangan hukum publik dan lapangan hukum privat. ${ }^{41}$ Pada konteks inilah maka hukum dalam hal ini UndangUndang Nomor 12 tahun 2006 tentang Kewarganegaraan Indonesia di Indonesia kemudian mengakomodir penerapan status kewarganegaraan ganda secara terbatas bagi anak yang lahir dari status perkawinan campuran, karena memang penerapan asas ius soli dan ius sanguinis sudah tidak memadai lagi untuk diterapkan pada konteks kasus perkawinan campuran.

\section{Penutup}

\subsection{Simpulan}

$$
\begin{aligned}
& \text { Anak di bawah umur yang memiliki } \\
& \text { kewarganegaraan ganda dapat menerima } \\
& \text { warisan dari orang tuanya yang melakukan } \\
& \text { perkawinan campuran, apabila: (a) perkawinan } \\
& \text { orang tuanya adalah sah dan tercatat; (b) anak } \\
& \text { belum genap berusia } 18 \text { tahun atau menikah; (c) } \\
& \text { setelah genap } 18 \text { tahun atau menikah, yang } \\
& \text { bersangkutan mengajukan menjadi warga } \\
& \text { negara Indonesia paling lambat } 3 \text { tahun. }
\end{aligned}
$$

40 Sudargo Gautama, Hukum Perdata Indonesia, CV. Sinar Bakti, Jakarta, 1995, hlm. 13

41 Susilo dan Pramuji R., Kitab Undang-undang Hukum Perdata dilengkapi Undang Undang No. 1 tahun 1974 tentang Perkawinan, Kompilasi Hukum Islam, Undang-undang No. 5 tahun 1960 tentang Peraturan Dasar Pokok-pokok Agraria, Rhedbook Publisher, 2008, hlm. 565-566. 
78 Raden Ine Sri Indriani dkk, Kedudukan Harta Warisan Anak....

\section{DAFTAR PUSTAKA}

\section{Buku}

Djubaidah, Neng. Pencatatan perkawinan dan Perkawinan Tidak Dicatat Menurut Hukum Tertulis di Indonesia dan Hukum Islam. Jakarta: Sinar Grafika, 2012.

Gautama, Sudargo. Hukum Perdata Internasional Indonesia, Jilid III Bagian I Buku ke-7. Bandung: Alumni, 1995.

Hadikusuma, Hilman. Hukum Perkawinan Indonesia Menurut Perundangan, Hukum Adat, Hukum Agama. Bandung: Mandar Maju, 1990.

Hardjowahono, Bayu Seto. Dasar-Dasar Hukum Perdata Internasional. Bandung: Citra Aditya Bakti, 2006.

Himlet, Harumiati Nuning. Perempuan dan Kewarganegaraan Perempuan dan Hukum, Menuju Hukum yang Berspektif Kesetaraan dan Keadilan. Jakarta: Yayasan Obor Indonesia, 2008.

Marzuki, Peter Mahmud. Penelitian Hukum, Cetakan ke -11. Jakrta: Kencana, 2011.

Meiliala, Djaja S. Hukum Perdata Dalam Perspektif BW. Bandung: Nuansa Aulia, 2013.

Muhammad, Abdulkadir. Hukum Perdata Indonesia. Bandung: Citra Aditya Bakti, 2014.

Natadimaja, Harumiati. Hukum Perdata Mengenai Hukum Perorangan dan Hukum Benda. Jakarta: Graha IImu, 2009.

Prodjodikoro, Wirjono. Hukum Perkawinan Bagi yang Beragama Islam (Suatu Tinjauan dan Ulasan Secara Sosiologi Hukum). Jakarta: Pradnya Paramita, 1997.

-. Hukum Perkawinan di Indonesia. Bandung: Sumur Bandung, 1994.

Purnamasari, Irma Devita. Kiat-kiat Cerdas, Mudah dan Bijak Memahami Masalah Hukum Waris. Bandung: Mizan, 2014.
Simorangkir, J.C.T. \& Woerjono Sastropranoto. Pelajaran Hukum Indonesia. Jakarta: Gunung Agung, 1997.

Susilo dan Pramuji R. Kitab Undang-undang Hukum Perdata dilengkapi Undang Undang No. 1 tahun 1974 tentang Perkawinan, Kompilasi Hukum Islam, Undang-undang No. 5 tahun 1960 tentang Peraturan Dasar Pokok-pokok Agraria. Rhedbook Publisher, 2008.

\section{Jurnal/ Makalah/ Internet}

Nuning Hallet, Mencermati Isi Rancangan UU Kewarganegaraan, http://www.mixedcouple.com, diakses 7 Januarii 2018.

Muhammad Fikri Podungge, Jenis-Jenis Penelitian di Bidang Keilmuan Hukum, fikripodungge.blogspot.com

Rahmadika Safira Edithafitri, "Hak Waris Anak Yang Lahir Dari Perkawinan Campuran Terhadap Hak Milik Atas Tanah", Lex Administratum, Vol. V/No. 7/Sep/2017

\section{Peraturan Perundang-undangan}

Kitab Undang Undang Hukum Perdata.

Undang Undang Nomor 1 tahun 1974 tentang perkawinan, Lembar Negara Republik Indonesia Nomor 1.

Undang Undang Nomor 17 Tahun 2016 Tentang Penetapan Peraturan Pemerintah Pengganti Undang-Undang Nomor 1 Tahun 2016 tentang Perubahan kedua Atas Undang Undang Nomor 23 Tahun 2002 Tentang Perlindungan Anak Menjadi Undang Undang, Lembar Negara Republik Indonesia Nomor 99.

UndangUndang Republik Indonesia Nomor 12 Tahun 2006 Tentang Kewarganegaraan Republik Indonesia Lembar Negara Republik Indonesia Nomor 63. 